\title{
Does Financial Development Spur Macroeconomic Policy Efficiency in the Cemac Countries? An Empirical Evaluation
}

\section{Samba MC* and Mbassi C}

University of Yaounde, Yaounde, Cameroon

\begin{abstract}
The main intent of this paper is to determine the extent to which financial development has contributed to the efficiency of macroeconomic policy, better represented by monetary policy, in the CEMAC area in the period spanning from 1986 to 2009. For this purpose, we use a methodology provided by Krause and Rioja (2006). These authors develop a methodology in which they derive policy efficiency measures and then assess how these measures are influenced by useful indicators of financial development. Our results show that the efficiency of the BEAC monetary policy is mixed among the CEMAC countries. While policy efficiency has improved in some countries, it has rather stagnated or declined in others. On the other hand, of the three measures of financial development used, only the measure for financial deepening is positively related to monetary policy efficiency. Our main indicator of financial development namely, domestic credit by banks to private sector as a percentage of GDP has any impact on the efficiency of monetary policy in the CEMAC area. Moreover, while the peg of the CFA Franc to the euro appears to have enhanced policy efficiency, the devaluation of the same currency rather impeded monetary efficiency in the CEMAC area.
\end{abstract}

Keywords: Financial development; Policy efficiency; Demand shock; Supply shock; CEMAC

\section{Introduction}

The financial crisis of 2007-08 and its aftermath of the worst global recession since the 1930s marked the end of the Great Moderation, a period of decreased macroeconomic volatility around the world since the mid-1980s. There is in fact an agreement among researchers that the latter part of the 1990s and the first years of the new millennium have evidenced a general improvement in macroeconomic performance in industrialized and developing countries alike. Both the level and variability of inflation were lower in the latter half of the 1990s than they were in the preceding ten years as documented for example by Cecchetti [1]. According to the same strand of research, output volatility has also been on the decline since the mid-1980s [2]. Many reasons have been given for this generalized improvement in macroeconomic outcomes around the world. Several authors have reported a link between the degree of central bank independence and both the level and variability of inflation. In fact, as argued by Cukierman et al. [3] economists and practitioners in the area of monetary policy generally believe that the degree of independence of the central bank from other parts of government affects the rates of expansion of money and credit and, through them, important macroeconomic variables such as inflation and the size of the budget deficit. This is evidenced in the earlier works of Alesina and Summers [4], Grilli et al. [5], Cukierman [6], and Cukierman et al. [3] who suggest that inflation and legal independence are negatively related. More recent studies, such as Crowe and Meade [7], also confirm these findings [8,9].

Other researchers have stressed the effect of specific elements within the monetary policy framework. These elements include the role of inflation targeting regimes, legal and political environment, the adoption of specific exchange rate regimes, and the effects of joining a monetary union. There is indeed a great concern, in the empirical field, about the outcomes of inflation targeting for those countries which have adopted an explicit target rate of inflation. Earlier studies $[10,11]$ observe no announcement effects of targets. Bernanke et al. [12] on their part examine how well variants of Inflation Targeting have worked in nine countries including Germany, Switzerland, New Zeeland, Canada, the United Kingdom, Sweden, Israel, Spain and Australia. They show that these countries have typically seen lower inflation, lower inflation expectations, and lower interest rates, although the adjustment of inflation expectations in New Zeeland, Canada, the United Kingdom and Sweden was gradual. Johnson [13] and to some extend Newmann and Von Hagen [14] also show that inflation targeting has been successful in the targeting countries.

As for change in output volatility, Clarida et al. [15] attribute much of its persistent decline to changes in the monetary policy regime. Another possibly explanation is that the world seems to have been more stable before the 2007-08 financial crisis. For Cecchetti [1], if there are no shocks hitting an economy, it will surely be stable.

The CEMAC $^{1}$ area has witnessed important changes on both its financial sector and the conduct of monetary policy since 1990. On October that year, the central bank launched a series of reforms that marked the renewal of monetary policy in the CEMAC area. Direct instruments were abandoned in favour of indirect instruments and monetary policy began to be managed in a forward-looking macroeconomic framework called Monetary Programming. The new deal of monetary policy was also accompanied by a vast banking reform and the launching in 1994 of the money market in which the central bank is supposed to play an important role. The central bank has been assigned the objective of monetary stability. It relies on the monetary programming framework to decide monetary aggregates growth

${ }^{1}$ C.E.M.A.C: Communauté Economique et Monétaire de l'Afrique Centrale. This is the French acronym for the Central African Economic and Monetary Community (C.A.E.M.C) which links together 6 countries (Cameroon, Central African Republic, Chad, Congo, Equatorial Guinea and Gabon)

*Corresponding author: Samba MC, University of Yaounde, Yaounde, Cameroon; E-mail: sambamichelcyrille@yahoo.fr

Received May 06, 2016; Accepted May 25, 2016; Published May 31, 2016

Citation: Samba MC, Mbassi C (2016) Does Financial Development Spur Macroeconomic Policy Efficiency in the Cemac Countries? An Empirical Evaluation Bus Eco J 7: 216. doi:10.4172/2151-6219.1000216

Copyright: (c) 2016 Samba MC, et al. This is an open-access article distributed under the terms of the Creative Commons Attribution License, which permits unrestricted use, distribution, and reproduction in any medium, provided the original author and source are credited. 
and refinancing objectives consistent with the realization of the final objective of monetary policy. For its interventions, the central bank has at its disposal three indirect instruments: liquidity management through a money market, interest rates and reserve requirements. Last but not least, the financial environment was enriched in 2003 by the launching of two stock exchange markets, the Douala Stock Exchange in Douala, Cameroon and the Central African Stock Exchange in Libreville, Gabon. However, until now, transactions on these two exchanges are still marginal with very low capitalisations.

Therefore, the main intent of this paper is to determine to which extent financial development has contributed to the efficiency of macroeconomic policy in the CEMAC area. For this purpose, we use a methodology provided by Krause and Rioja [16] in order to assess the importance of financial institutions on macroeconomic stabilisation. These authors develop a methodology in which they derive policy efficiency measures and then assess how these measures are influenced by useful indicators of financial development. Throughout the paper, we admit, as in Cecchetti [1] and Krause and Rioja [16] that macroeconomic policy is better monetary policy, although many other factors can contribute to improved overall economic outcomes [1]. As noted by Mishkin [17] fiscal policy has lost its luster as a tool to stabilize the aggregate economy because of doubts about the ability to time fiscal policy actions to obtain desirable stabilization outcomes as well as concerns about budget deficit. For those reasons, both economists and politicians in recent years advocate that the stabilization of output and inflation be left to monetary policy.

The economic profession has also become more supportive of price stability as the long-run primary goal for a central bank. According to Cecchetti [1], monetary policies of the 1990s may have been more efficient than those in the 1980s to explain the widespread improvement in macroeconomic outcomes. Therefore in our study macroeconomic policy efficiency and monetary policy efficiency shall be used in an interchangeable manner. We use quarterly data from 1986 to 2009 and due to further transformations; the period under consideration goes from 1991 to 2009. Our results show that the efficiency of macroeconomic policy is mixed among the CEMAC countries. While policy efficiency has improved in some countries, it has unfortunately worsened in others. On the other hand, of the three indicators of financial development used, only the measure for financial deepening is positively related to monetary policy efficiency. Our main indicator of financial development namely, domestic credit by banks to private sector as a percentage of GDP has any influence on monetary policy efficiency in the CEMAC area. Moreover, while the peg of the CFA Franc to the euro appears to have enhanced policy efficiency, the devaluation of the same currency has rather reduced monetary policy efficiency in the CEMAC area. The rest of the paper is as follows: a review of literature on the relation between financial development and monetary policy efficiency is presented in section 2 . In section 3 , we take a preliminary look at the data on macroeconomic performance and financial development for the CEMAC countries. A theoretical approach of measuring policy performance is developed in section 4 and the estimated method of relating financial development to policy efficiency is discussed in section 5. Our main results are presented in section 6 while section 7 concludes.

\section{Literature Review}

Many studies have already looked at the relationship between financial sector and monetary policy. Most of these studies assess the role of financial intermediaries on monetary policy transmission and are mainly based on the so-called credit view of monetary policy. The credit view takes as a point of departure the assumption that financial markets are characterized by imperfections. In fact, information asymmetries between borrowers and lenders and the resulting agency problems translate into a wedge between the cost of external and internal finance. The size of external finance premium depends on the quality of the balance sheet of the borrower and varies with the level of interest rates as set by monetary authorities. Amplification comes through a financial accelerator effect. In fact, as the balance sheet quality improves, due to better economic conditions, the external finance premium declines. The credit channel literature distinguishes two different mechanisms, the firm balance sheet and the bank lending channel. According to Jimboream [17], the bank lending channel ascribes a special role to banks in the monetary transmission mechanism, stipulating that monetary tightening can affect not only the demand for loans, but also the supply of loans which in turn, further affects investment and consumption. Two hypotheses are crucial for the bank lending theory: (i) the imperfect substitution between credit and other assets on banks' balance sheets, and (ii) the imperfect substitution between credit and other forms of financing on firms' balance sheets. In the empirical literature, the relevance of the bank lending channel has been a controversial issue, due to a fundamental identification problem, that is identifying shifts in loan demand from shifts in loan supply. Evidence that both output and bank loans fall after a monetary tightening does not identify whether the decline in loan volume reflects a constriction of loan supply or a dampening of loan demand through the traditional interest rate mechanism. A fall in aggregate lending after a monetary contraction may be driven by demand, rather than supply. Studies that analyse the response of aggregate credit to monetary shocks, in the spirit of Bernanke and Blinder [18], are therefore inconclusive as regards the existence of a bank lending channel. To address this identification problem, several studies have considered disaggregated data. Kashyap and Stein [19] using disaggregated U.S. bank balance sheet data over the period 1976-1992, find that smaller banks' loan portfolio is more affected by monetary policy changes; while Kashyap and Stein [20] find evidence that the loan portfolios of smaller, more illiquid banks are most responsive to monetary policy shocks.

How financial structure affects channels of monetary policy is also an important issue in the literature. In a cross-country study, Cecchetti [21] relates the estimates of the impact of monetary policy on output and inflation to an overall indicator of financial structure, which reflects the presence of small banks, the health of the banking system, and the possibility of direct access to the capital market by firms. He finds a clear relationship between the estimated strength of monetary policy and the overall indicator for financial structure. Countries with many small banks, less healthy banking systems, and poorer direct access of firms to capital markets display a greater sensitivity to monetary policy changes than countries with big, healthy banks and deep, welldeveloped capital markets. Rather than using an overall indicator of financial structure, Elbourne and De Haan [22] construct various indicators of financial structure in the Central and Eastern European Countries accessing the European Union. Globally, their results do not confirm the earlier findings by Cecchetti [21].

Some other authors have even linked financial innovation to monetary policy transmission. They argue that financial innovation might have played an important role in the transmission of monetary policy [23]. Securitization might have increased risk-taking incentives provided by low interest rates further, as might have the increasing use of different derivatives. Norden et al. [24] find evidence that banks 
passed on risk management benefits of credit derivatives to corporate borrowers in the U.S. They also find that the magnitude of this effect remained the same during the Global Financial crisis and that banks with larger holdings of credit derivatives cut their lending by less than other banks and faced lower non-performing assets.

If this abundant literature tries to assess the nexus between finance and monetary policy transmission, few studies are yet to clearly relate financial development to monetary policy efficiency. Posen [18] argues for the importance of establishing societal forces support for the objective of price stability and claims that effective financial opposition to inflation is relevant in order for monetary policy institutions to successfully achieve stabilization objectives. His argument is that central bank decisions not only reflect its institutional capabilities and legal constraints, but that such determinations also respond to the political environment. Therefore, the central bank can guarantee price stability only as long as the financial sector is ready to support policies associated with reducing inflation: the more developed is the financial sector, the more successful will be stabilization policies. Cecchetti and Krause [25] find evidence suggesting that an improvement in the depth of the financial sector and the intermediation process, measured by a less centrally controlled banking system, has contributed to the reduction in inflation and output variability. Krause and Rioja [16] on their part derive monetary policy efficiency measures (PEMs) and employ them to analyse the impact that the size and depth of the banking sector and the capital sector have on policy performance. Actually, they find that more developed financial markets, controlling for other variables, significantly contribute to explaining a more efficient monetary policy implementation.

\section{Empirical Facts on CEMAC Countries}

Before going deep in our study, we first present in this section, some empirical facts on macroeconomic outcomes and financial development for five countries ${ }^{2}$ of the CEMAC area. To this end, we analyse the behaviour of inflation and output for two periods, 1986 to 1997 and 1998 to 2009 using quarterly data. Figure 1 presents the change in the variability of inflation and output for Cameroon, the Central African Republic, Chad, Equatorial Guinea and Gabon. Inflation variability is measured as the squared deviation from a target of 3\%, the declared objective of the central bank. As for output variability, it is measured as the squared deviation

${ }^{2}$ Due to data unavailability, the Republic of Congo is not included in this study.

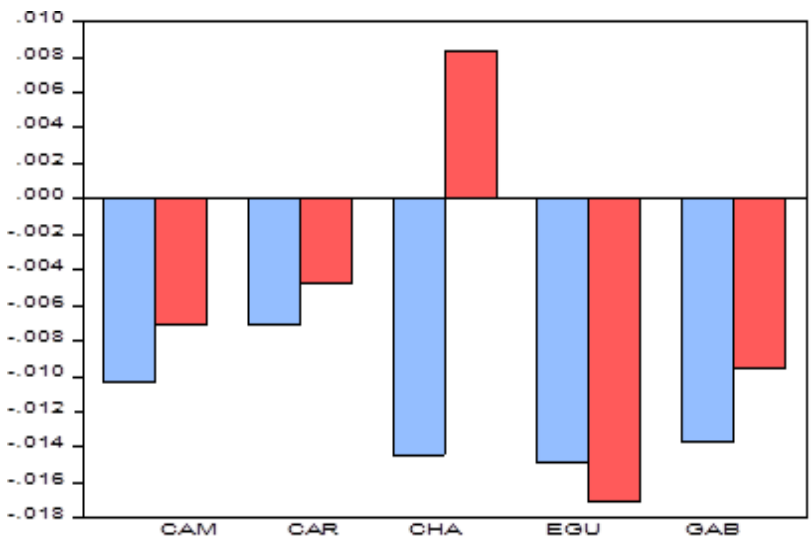

Figure 1: Change in inflation and output variability (1986-1997 and 19982009). Source: computed by authors from International Financial Statistics (2013), IMF. CAM: Cameroon; CAR: Central African Republic; CHA: Chad; EGU: Equatorial Guinea; GAB: Gabon. from its potential level obtained from a Hodrick-Prescott filter.

As shown in Figure 1, macroeconomic performances have improved markedly in almost all the five countries. Inflation variability has decreased in all the countries, with more pronounced reduction in Chad, Equatorial Guinea and Gabon. Output volatility has also fallen, with only Chad showing an increase in the period under consideration. Therefore, one should at first sight conclude that there has been an improvement in macroeconomic performance in the CEMAC area, especially during the period spanning from 1998 to 2009.

The preferred measure of financial development in the recent literature has been domestic credit by banks and other financial institutions to the private sector (Private Credit) as a share of GDP [26-28]. In our case, we use bank credit to private sector (Percentage of GDP) as a measure of financial development. Figure 2A shows the evolution of this measure from 1986 to 2009 . One can notice a gradual and persistent decline in bank loans to private sector in all the five countries especially in Gabon and Equatorial Guinea indicating a decline in financial development. From an average level of $25 \%$ at the beginning of the period, bank credit to private sector accounts only for less than $10 \%$ of GDP in 2009. Figure 2B shows for each country the average level of bank credit to private sector (\% GDP) between 1986-1997 and 1998-2009 sub-periods. There is a clear indication that financial development in the second period is lesser than in the first one. The only improvement is in Central African Republic where a slight increase is evidenced. Moreover, the level of financial development in the CEMAC countries is widely lesser than the sub-Saharan Africa (SSA) average. While the average for SSA is about $52,98 \%^{3}$, it is only around $15 \%$ for the CEMAC area.

Using the level of liquidity (M1 in \% of GDP) as an indicator of financial development leads to the same conclusion as stated above. Figure 3 shows that the level of financial development is very weak for all the five countries. Moreover, except Cameroon and to some extent Gabon where there is a certain improvement, this measure of financial development has decreased during the second sub-period.

Overall, stylized facts attest that financial development in the CEMAC area has gradually declined throughout the period 1986-2009 and its level is well below the average level in Sub-Saharan Africa. On the other hand, there is an indication that the region has recorded

${ }^{3}$ This average is computed for the period 1986-2009. World Development Indicators (2011) database.

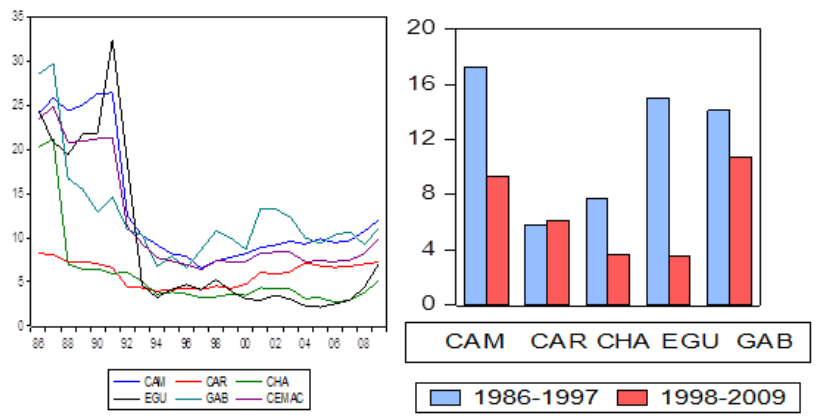

Figure 2: Evolution of bank credit to private sector (1986-2009) and Average level of Bank credit to private sector between 1986-1997 and 1998-2009 sub-periods. Source: International Financial Statistics 2013 (International monetary Fund). 


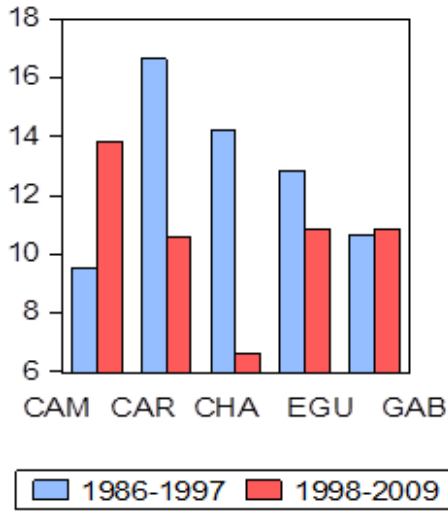

Figure 3: Evolution of liquidity (M1 in \% of GDP). Source: International Financial Statistics 2013 (International monetary Fund).

better macroeconomic outcomes in the period between 1998 and 2009 .

\section{Theoretical Approach of Measuring Monetary Policy Performance}

To measure monetary policy performance, our study uses a policy efficiency measure (PEM) following the methodology described by Krause and Rioja [16]. Their approach is based on an aggregate demand-aggregate supply (AD-AS) model as initially developed by Krause [29]. This methodology is interested in knowing how aggregate shocks affect inflation and output gap. Krause and Rioja [16] define the effects of shocks as suggested by Cecchetti [30]. A positive demand shock (d) increases both inflation and output gap while a positive supply (s) shock increases inflation and rather reduces output gap. The effects are well described by the following equations:

$$
\begin{aligned}
& \pi_{t}=\alpha_{\pi d} d+\alpha_{\pi s} s \\
& y_{t}=\alpha_{y d} d-\alpha_{y s} s
\end{aligned}
$$

Where $\pi_{p}$, denotes the deviation of inflation from its target level; $y_{\mathrm{t}}$ the output gap. $d$ and $s$ represent demand and supply shocks, respectively. The coefficients $\alpha_{\pi \mathrm{d}}, \alpha_{\pi \mathrm{s}}, \alpha_{\mathrm{yd}}$, et $\alpha_{\mathrm{ys}}$ are all positive and depend on the response of monetary policy to shocks and to the structure of the economy [29]. From (1) and (2) and assuming that demand and supply shocks are uncorrelated, Krause and Rioja [16] derive the actual variances of inflation $\left(\sigma_{\pi}^{2}\right)$ and output $\left(\sigma_{y}^{2}\right)$ as well as their covariance $\left(\sigma_{\pi y}\right)$. Following Cecchetti and Krause [25], the authors then define a primarily policy efficiency measure $(\mathrm{H})$ as follows:

$$
H \equiv \sigma_{\pi}^{2} \sigma_{y}^{2}-\left(\sigma_{\pi y}\right)^{2}=\left(\alpha_{\pi d} \alpha_{y s}+\alpha_{\pi s} \alpha_{y d}\right)^{2} \sigma_{d}^{2} \sigma_{s}^{2}>0
$$

It is assumed that under optimal monetary policy, effects of demand disturbances on inflation and output gap are fully neutralized [15]. Consequently, inflation and output gap depend exclusively on the magnitude of the supply shocks, that is $\alpha_{\pi d}=\alpha_{y d}=0$. Optimal policy therefore implies:

$$
H(\text { optimal })=0
$$

That is, the closer to 0 is $H$, the smaller are the effects of demand shocks, and the more efficient is the policy. The efficiency of monetary policy is in fact appreciated relatively to its ability to offset the effects of demand shocks.

To undertake the estimation of $H$, Krause and Rioja [16] suggest the linearization of equation (3), which leads to two components. A systematic part which depends on the stance of the actual policy, and a part which is function of aggregate disturbances.

$$
\ln H=h=2 \ln \left(\alpha_{\pi d} \alpha_{y s}+\alpha_{\pi s} \alpha_{y d}\right)+\ln \sigma_{d}^{2}+\ln \sigma_{s}^{2}
$$

As there is no consensus about the direct estimation of aggregate disturbances, Krause and Rioja [16] provide an alternative method. They suggest that both demand and supply shocks for country $i$ at period $t$, be a combination of a country specific effect $(\Gamma)$, a common $\operatorname{shock}(\Phi)$ and a residual shock $(\xi)$. So,

$$
\begin{aligned}
& d_{i t}=\Gamma_{\mathrm{d}, \mathrm{i}} * \Phi_{\mathrm{d}, \mathrm{t}} * \xi_{\mathrm{d}, \mathrm{it}} \\
& s_{i t}=\Gamma_{\mathrm{s}, \mathrm{i}} * \Phi_{\mathrm{s}, \mathrm{t}} * \xi_{\mathrm{s}, \mathrm{it}}
\end{aligned}
$$

Assuming that the three components of each shock are orthogonal, we have:

$$
\begin{aligned}
& \ln \sigma_{d}^{2}=\ln \operatorname{Var}\left(d_{i t}\right)=\ln \operatorname{Var}\left(\Gamma_{\mathrm{d}, \mathrm{i}}\right)+\ln \operatorname{Var}\left(\Phi_{\mathrm{d}, \mathrm{t}}\right)+\ln \operatorname{Var}\left(\xi_{\mathrm{d}, \mathrm{it}}\right) \\
& \ln \sigma_{s}^{2}=\ln \operatorname{Var}\left(s_{i t}\right)=\ln \operatorname{Var}\left(\Gamma_{\mathrm{s}, \mathrm{i}}\right)+\ln \operatorname{Var}\left(\Phi_{\mathrm{s}, \mathrm{t}}\right)+\ln \operatorname{Var}\left(\xi_{\mathrm{s}, \mathrm{it}}\right)
\end{aligned}
$$

Setting that $\gamma_{i}=\ln \operatorname{Var}\left(\Gamma_{\mathrm{d}, \mathrm{i}}\right)+\ln \operatorname{Var}\left(\Gamma_{\mathrm{s}, \mathrm{i}}\right) ; \quad \phi_{t}=\ln \operatorname{Var}\left(\Phi_{\mathrm{d}, \mathrm{t}}\right)+\ln \operatorname{Var}\left(\Phi_{\mathrm{s}, \mathrm{t}}\right)$; $\varepsilon_{i t}=\ln \operatorname{Var}\left(\xi_{\mathrm{d}, \mathrm{it}}\right)+\ln \operatorname{Var}\left(\xi_{\mathrm{s}, \mathrm{it}}\right)$ equation (5) can be can be rewritten as follow:

$$
h_{i t}=P E M_{i t}+\gamma_{i}+\phi_{t}+\varepsilon_{i t}
$$

Where $\gamma_{\mathrm{i}}$ is a country specific effect; $\phi_{\mathrm{t}}$ a time-varying common component; and $\varepsilon_{\mathrm{it}}$, the residual. The PEM is identified as the adjusted (net of shocks) monetary policy efficiency measure and it is not directly observable. Therefore, we estimate the unadjusted index $h_{i t}$. All other things equal, a lower PEM results in a smaller value for $\mathrm{h}$ (and subsequently $\mathrm{H}$ ), which indicates a more efficient monetary policy.

\section{Data and Empirical Model}

\section{Data}

Our study deals with the relationship between financial development and the efficiency of macroeconomic policy, better represented by monetary policy. We consider five countries of the CEMAC area due to insufficient data for the Republic of Congo. The countries under consideration are therefore: Cameroon, Central African Republic, Equatorial Guinea, Gabon and Chad. We use quarterly data spanning from 1986 to 2009.

In our empirical model, the dependent variable is the unadjusted PEM $(h)$ of which the theoretical construction is presented in the previous section. We use three measures of financial development. The first measure is the level of financial deepening (LIQUID) measured as the ratio of the monetary aggregate M1 on GDP. The use of this indicator dates back to Goldsmith [31] who presumes a positive relationship between the size of financial system and both supply and quality of financial services. As stated earlier, the preferred measure of financial development in the recent literature has been domestic credit by banks and other financial institutions to the private sector as a share of GDP. Although it is not a direct measure of efficiency, it captures part of it; since it excludes credit to the private sector by the central bank, assuming the later less efficient than private intermediaries in allocating resources [32]. According to Levine et al. [33], higher levels of domestic credit by banks and other financial institutions to the private sector as a share of GDP indicate higher levels of financial services and therefore greater financial intermediary development. In the case of the CEMAC area, the indicator considered is Credit, that is, bank credit to private sector as a share of GDP. 
Our third measure of financial development is financial liberalization. In fact the new deal of monetary policy in the CEMAC area, launched in the 1990s was supported by a vast banking reform and a move towards market mechanisms in the region. Following McKinnon [34] and Shaw [35] a more liberalized financial sector is characterized by high interest rates. Therefore, we use the real ex-post interest rate as the indicator of financial liberalization (LIBER) defined as the difference between the bank lending rate and the inflation rate. We also considered two dummy variables in this study. The first dummy takes into account the devaluation of the CFA franc in 1994. It is assigned the value 0 before devaluation and 1 after. The second dummy is related to the peg in 1999 , of the CFA franc to the euro. This dummy takes the value 0 before this date and 1 after.

All the data are from International Financial Statistics (IFS) database of the International Monetary Fund (IMF).

\section{Empirical model}

Following the theoretical approach, the empirical estimation of the PEM is done in three steps as in Krause and Rioja [16]. In the first step we compute for each country $\sigma_{\pi}^{2}, \sigma_{\mathrm{y}}^{2}$, and $\sigma_{\pi \mathrm{y}}$ which are variance of inflation, variance of output gap and the covariance between the two variables, respectively. We use rolling averages of 20 quarters to compute those variables. Due to these transformations, the new time span goes from 1991 to 2009. Inflation is defined as the deviation of CPI inflation from its linear trend and output gap is the deviation of real output from the trend obtained by applying the Hodrick-Prescott filter. In the next step we introduce the previous variances and covariance in equation (3) in order to derive the unadjusted estimate $\hat{h}$ of $\hat{H}$ (PEM). Finally, we adjust $\hat{h}$ by introducing country specific effects $\left(\gamma_{\mathrm{i}}\right)$, time specific effect $\left(\phi_{\mathrm{t}}\right)$ and the residual $\left(\varepsilon_{\mathrm{it}}\right)$ as stated in equation (10).

For consistency, except the 2 dummies, all the other variables are computed using rolling averages of 20 quarters. Consequently, introducing country and time specific effects, our estimated equation is as follows:

$$
h_{i, t}=\beta_{1} \text { CREDIT }_{i, t}+\beta_{2} \text { LIQUID }_{i, t}+\beta_{3} \text { LIBER }_{i, t}+\beta_{4} \text { DEVAL }_{t}+\beta_{5} E U R O_{t}+\gamma_{i}+\phi_{t}+\varepsilon_{i t}
$$

An efficient policy is characterized by a decreasing and small values of $h$ so, we assume the coefficients $\beta_{1}, \beta_{2}$ and $\beta_{3}$ all negative implying that financial development improves macroeconomic policy efficiency.

\section{Results}

According to Krause and Rioja [16] a decreasing or lower value of the PEM is associated with more efficient policy. Results of the

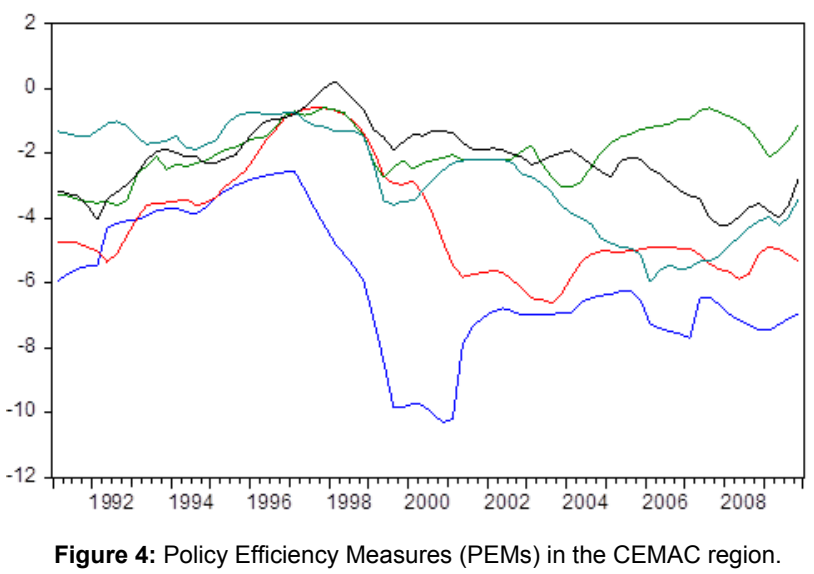

computation of the PEMs are displayed in Figure 4. At first sight, PEMs in all the five countries are very low, ranging from 0.23 in Equatorial Guinea to -10.28 in Cameroon. One could therefore conclude for improved policy efficiency. However, it is the evolution of the measure that matters much, rather than the levels obtained. In their sample of 37 countries, Krause and Rioja [16] show that in most of the countries (except Japan, Hungary, South Korea and Philippines), unadjusted PEMs gradually decrease all over the period under consideration. At the end of the period, PEMs always end two or three times lower than those of the starting period.

There are three distinct sub-periods in the evolution of policy efficiency in the CEMAC area. As it is shown in Figure 4, PEMs in all the five countries registered a constant increase from 1991 to the eve of 1998. Just after 1998 and mainly from 1999 there is evidence of a decrease of PEMs in all the countries with different magnitudes. While sharp in Cameroon and Central African Republic, the decline was just tiny in the rest of the sample. It's worth noting that as from 1999, CEMAC countries moved from pegging their currency to the French currency to the euro. Finally, the decline of the PEMs was followed either by an increase around the period 2002-2004 like in Cameroon, the Central African Republic and Gabon; or by both a stagnation and an increase like in Equatorial Guinea and Chad. Overall, our results indicate that from 1991Q1 to 2009Q4 PEMs globally decreased in three countries including Gabon, Cameroon and Central African Republic. Changes in the PEMs (the difference between the starting period index and that of the end period) in the three countries are respectively $-2.07,-1.01$, and -0.6 , suggesting an improvement in monetary policy efficiency. On the contrary, monetary policy efficiency seems to have worsened in Chad and Equatorial Guinea, as changes in PEMs are respectively 2.17 and 0.36 . According to those statistics, one remains inconclusive about the net improvement of macroeconomic policy in the CEMAC area in the entire period under consideration. However, there is some evidence that the peg to euro in 1999 has led to more efficient policy in CEMAC area.

Useful statistics on our variables are displayed in Tables 1 and 2.

One can notice from Table 1 that the average credit by banks to the private sector is low, with only Cameroon and Gabon approaching the level of $50 \%$ of GDP. This tendency does not change when the two other indicators of financial development are considered. In Table

\begin{tabular}{|l|c|c|c|c|c|}
\hline & CAM & CAR & CHA & EGU & GAB \\
\hline PEM & $-6,0282$ & $-4,1241$ & $-1,9206$ & $-2,2012$ & $-2,7528$ \\
\hline CREDIT (\%) & 50,0118 & 22,4500 & 18,9665 & 31,1718 & 43,0087 \\
\hline LIQUID (\%) & 36,7932 & 62,5846 & 47,3318 & 30,0897 & 39,3936 \\
\hline LIBER (\%) & 10,2744 & 10,0212 & 9,8718 & 10,3564 & 9,9815 \\
\hline
\end{tabular}

Table 1: Country's averages of the main variables (1991.1-2009.4).

\begin{tabular}{|l|c|c|c|c|c|c|}
\hline Variables & Pem & Credit & Liquid & Liber & Deval & Euro \\
\hline Mean & $-3,405375$ & 0,331217 & 0,432386 & 0,070772 & 0,842105 & 0,578947 \\
\hline Max. & 0,232702 & 1,035092 & 0,809501 & 0,114435 & 1 & 1 \\
\hline Min. & $-10,28747$ & 0,098723 & 0,181298 & 0,037078 & 0 & 0 \\
\hline Std. Dev. & 2,134697 & 0,222091 & 0,143735 & 0,01883 & 0,365123 & 0,494379 \\
\hline Pem & 1 & & & & & \\
\hline Credit & $-0,108456$ & 1 & & & & \\
\hline Liquid & $-0,025009$ & 0,10315 & 1 & & & \\
\hline Liber & 0,214544 & 0,596192 & 0,384116 & 1 & & \\
\hline Deval & $-0,017436$ & $-0,609868$ & $-0,333349$ & $-0,614559$ & 1 & \\
\hline Euro & $-0,399294$ & $-0,50537$ & $-0,289446$ & $-0,785062$ & 0,507752 & 1 \\
\hline \multicolumn{7}{r}{ Table 2: Descriptive statistics $(1991.1-2009.4)}$. \\
\end{tabular}


2, PEM shows negative correlations, as expected, with CREDIT and LIQUID, but these correlations are weak. On the other hand, the correlation between EURO and PEM seems strong and negative, as expected. However, the proper relationships must be established by our econometric estimation of Equation (11)

We estimated several specifications of equation (11) and results are displayed in Table 3. For all the specifications except the last one, we performed random effects estimations following the results of the Haussman test as presented in Table 4 . Under null hypothesis, the test confirms the presence of random effects.

The first specification has as unique explanatory variable, the level of liquidity (LIQUID) or financial deepening. As hypothesized, results show that financial development measured by financial deepening improves significantly monetary policy efficiency. Indeed, the coefficient affected to this variable is negative $(-1.85)$ and significant (5\%). So, the more the financial sector is deep, the more the central bank is able to ensure macroeconomic stability. Economically, results show that a $10 \%$ increase in financial deepening is associated with a reduction in the PEM of 1.85. The average PEM for our sample equals -3.405 according to Table 2. Hence, a 10\% increase in LIQUID would be associated with a reduction in the PEM of about5.43\%.However, as already stated, financial deepening is not an excellent indicator of financial development [36]. So we have to appreciate the role of bank credit to the private sector (in \% of GDP).

Specification 2 in Table 3 shows that financial development measured by bank domestic credit to private sector is not a determinant of monetary policy efficiency. Indeed, the coefficient associated with this variable does not have the hypothesized negative sign (0.092) and is not significant $(0.853)$. This result should be explained by the low and decreasing level of bank loans to the private sector, as demonstrated in Section 2 above. In such conditions, monetary policy might be

\begin{tabular}{|l|c|c|c|c|c|c|c|}
\hline $\begin{array}{l}\text { Dependent } \\
\text { variable: } \\
\text { Unadjusted } \\
\text { PEM( h) }\end{array}$ & $\mathbf{( 1 )}$ & $\mathbf{( 2 )}$ & $\mathbf{( 3 )}$ & $\mathbf{( 4 )}$ & $\mathbf{( 5 )}$ & $\mathbf{( 6 )}$ & $\mathbf{( 7 )}$ \\
\hline CONSTANT & $-2,311$ & $-3,379$ & $-3,227$ & $-2,502$ & $-3,276$ & $-2,387$ & $-2,457$ \\
\cline { 2 - 8 } & $(0,019)$ & $(0,000)$ & $(0,001)$ & $(0,001)$ & $(0,002)$ & $(0,049)$ & $(0,000)$ \\
\hline CREDIT & & 0,092 & & 0,604 & 0,135 & & 0,729 \\
\cline { 2 - 9 } & & $(0,853)$ & & $(0,255)$ & $(0,792)$ & & $(0,185)$ \\
\hline LIQUID & $-1,857$ & & & $-2,223$ & & $-1,873$ & $-2,312$ \\
\cline { 2 - 8 } & $(0,019)$ & & & $(0,009)$ & & $(0,020)$ & $(0,008)$ \\
\hline LIBER & & & $-0,946$ & & $-1,335$ & 0,866 & $-0,788$ \\
\hline DEVAL & 1,276 & 1,486 & 1,446 & 1,415 & 1,479 & 1,288 & 1,431 \\
\cline { 2 - 8 } & $(0,000)$ & $(0,000)$ & $(0,000)$ & $(0,000)$ & $(0,000)$ & $(0,000)$ & $(0,000)$ \\
\hline EURO & $-2,359$ & $-2,261$ & $-2,294$ & $-2,305$ & $-2,288$ & $-2,339$ & $-2,313$ \\
\hline & $(0,000)$ & $(0,000)$ & $(0,000)$ & $(0,000)$ & $(0,000)$ & $(0,000)$ & $(0,000)$ \\
\hline
\end{tabular}

Note: $p$-values are in brackets.

Table 3: Financial development and policy efficiency: A random effects estimation.

\begin{tabular}{|c|c|c|c|}
\hline Specification & $\boldsymbol{X}^{\mathbf{2}}$ Statistic & DF & Probability \\
\hline$(1)$ & 0 & 3 & 1 \\
\hline$(2)$ & 1,712781 & 3 & 0,6341 \\
\hline$(3)$ & 0,442082 & 3 & 0,9314 \\
\hline$(4)$ & 0 & 4 & 1 \\
\hline$(5)$ & 0 & 4 & 1 \\
\hline$(6)$ & 0 & 4 & 1 \\
\hline
\end{tabular}

Note: DF: Degree of Freedom.

Table 4: Haussman test. ineffective because of the weakness of the credit channel of monetary policy. Moreover the transmission mechanism is also weakened by the excess reserves of banks, as this is one of the main features of the banking sector in the CEMAC area. Saxegaard [37] using a threshold SVAR model, finds that excess reserves, defined as banks' holding of cash and deposits at the central bank in excess of statutory requirements, negatively affect the transmission of monetary policy in CEMAC area.

Specification 3 leads to the same conclusion as in specification 2. Financial liberalisation does not improve the efficiency of monetary policy. Though the coefficient on to this variable is negative (-0.94), it is however not significant (0.871).

Specification 4 takes into account both the variables CREDIT and LIQUID and as above, the level of financial deepening still improves the efficiency of monetary policy, contrary to bank credit. Specification 5 uses both bank credit to private sector and financial liberalisation. Both variables show no significant effect on monetary policy efficiency.

In specification 6 where LIQUID and LIBER are used simultaneously, only LIQUID affects significantly policy efficiency as hypothesized. Finally, the last specification takes into account the three variables. Even in this case, only financial deepening improves significantly policy efficiency in the CEMAC area.

In all the specifications, it is clear that the peg to euro has a positive and significant effect on monetary policy efficiency in the CEMAC area. The coefficient of the variable for this peg, EURO, takes the negative hypothesized sign, suggesting an improvement in policy efficiency. This variable is significant at a $1 \%$ level. This result confirms the declining trend of PEMs since 1999, as discussed above. Therefore, thanks to the peg of its currency to euro, BEAC monetary policy enjoys more efficiency stemming from the credibility of the European Central Bank. Musa et al. argue that a high share of trade with a dominant partner or dominant partners makes it attractive to adopt a fixed rate vis-à-vis this country or those countries, especially if inflation in that country or those countries is low. The peg to euro therefore seems to have imposed macroeconomic discipline to the CEMAC countries. As for the devaluation, results show that this variable affects in a negative way the efficiency of monetary policy. Indeed, in all the specifications, the coefficient on devaluation is positive and significant at $1 \%$. Accordingly, one could suggest that the devaluation of the CFA Franc in January 1994 dampened macroeconomic policy efficiency in the region, contrary to the welfare effect it was supposed to produce. Figure 4 shows an increasing trend in PEMs around 1994, the year of devaluation.

\section{Conclusion}

The main objective of this paper was to assess the impact of financial development on macroeconomic policy efficiency in the CEMAC area over the period 1986Q1-2009Q4. Throughout the paper, we admit that macroeconomic policy efficiency is better monetary policy. Accordingly, we constructed a Policy Efficiency Measure (PEM) following the methodology proposed by Krause and Rioja [16]. The results show that the efficiency of the BEAC monetary policy is mixed among the CEMAC countries. While policy efficiency has improved in Cameroon, Gabon and to a certain extent Central African Republic, it has rather stagnated or declined in Equatorial Guinea and Chad. In our model we used three indicators of financial development namely domestic bank loans to private sector (\% of GDP), financial deepening (\% of M1 to GDP) and financial liberalisation (real ex post interest rate). We found that only financial deepening improves significantly monetary policy efficiency. Our main measure of financial 
Citation: Samba MC, Mbassi C (2016) Does Financial Development Spur Macroeconomic Policy Efficiency in the Cemac Countries? An Empirical Evaluation. Bus Eco J 7: 216. doi:10.4172/2151-6219.1000216

Page 7 of 7

development, that is, domestic credit by banks to private sector does not have a positive impact on policy efficiency. Moreover, of the two dummy variables used, the results show that while the peg of the CFA Franc to the euro appears to have enhanced policy efficiency, the devaluation of the same currency in 1994 has rather reduced monetary policy efficiency in the CEMAC area

Therefore, while monetary authorities in the CEMAC area should continue to exploit the efficiency gains stemming from the peg of the local currency to the euro, more still to be done at the internal level, for the financial sector to be the central bank main support for its stabilization objectives, as suggested by Posen [18]. A recent study by Gori et al. [38] argues that low-income developing countries are typically more credit constrained than advanced economies, and capital inflows, mainly foreign direct investments, can be an important source of financial deepening (development) for those economies to stimulate investment and efficient allocation of resources. This might be, among other things, one of the solutions for the BEAC to enhance its policy efficiency.

\section{References}

1. Cecchetti SG, Flores-Lagunes A, Krause S (2006) Has Monetary Policy Become More Efficient? A cross-Country Analysis.The Economic Journal 116: 408-433.

2. Kent C, Smith K, Holloway J (2005) Declining Output Volatility: What Role for Structural Change? The Changing Nature of the Business Cycle pp: 146-180.

3. Cukierman A (1992) Central Bank Strategy, Credibility, and Independence. MIT Press, Cambridge, MA.

4. Alesina A, Summers L (1993) Central Bank Independence and Macroeconomic Performance: Some Comparative Evidence. Journal of Money, Credit and Banking 25:151-162.

5. Grilli V, Masciandaro D, Tabellini G (1991) Political and Monetary Institutions and Public Financial Policies in the Industrial Countries. Economic Policy 13: 341-392.

6. Cukierman A, Webb S, Neyapti B (1992) Measuring the Independence of Central Banks and its Effect on Policy Outcomes. The World Bank Economic Review 6: 353-398.

7. Crowe C, Meade EE (2008) Central Independence and Transparency: Evolution and Effectiveness. European Journal of Political Economy 24: 763-777.

8. Berger H, De Haan J, Eijffinger SCW (2001) Central Bank Independence: An Update of Theory and Evidence. Journal of Economic Surveys 51: 3-40.

9. Cukierman A (2008) Central Bank Independence and Monetary Policymaking Institutions- Past, Present and Future. European Journal of Political Economy 24: $722-736$

10. Laidler DEW, Robson WBP (1993) The Great Canadian Disinflation: The Economics and Politics of Monetary Policy in Canada1988-1993. Policy Study, Howe Institute.

11. Bowen A (1995) British Experience with Inflation Targeting. Leonardo Leiderman and Lars, London: CEPR.

12. Bernanke BS, Laubach T, Mishkin, Posen A (1999) Inflation Targeting: Lessons from the International Experience. Princeton: Princeton University Press

13. Johnson D (2003) The Effects of Inflation Targets on the Level of Expected Inflation in Five Countries. The Review of Economics and Statistics 85: 1076-1081.

14. Neumann MJM, von Hagen J (2002) Does Inflation Targeting Matter? The Federal Reserve Bank of St. Louis Review 84: 127-148.

15. Clarida R, Galí J, Gertler M (1999) The Science of Monetary Policy: A New Keynesian Perspective. Journal of Economic Literature 37: 1661-1707.

16. Krause S, Rioja F (2006) Financial Development and Monetary Policy Efficiency. Georgia State University Working paper.

17. Jimborean R (2009) The Role of Banks in the Monetary Policy Transmission in the New EU Member States. Economic Systems 33: 360-375.

18. Posen AS (1995) Declaration are not Enough: Financial Sector Sources of Central Bank Independence. NBER Macroeconomics Annual, MIT Press, Cambridge, MA.

19. Kashyap AK, Stein (1995) The Impact of Monetary Policy on Bank Balance Sheets. Carnegie-Rochester Conference Series on Public Policy 42: 151-195.

20. Kashyap AK, Stein JC (2000) What Do a Million Observations on Banks Say About the Transmission of Monetary Policy? The American Economic Review 90: $407-428$.

21. Cecchetti SG (1999) Legal Structure, Financial Structure, and the Monetary Policy Transmission Mechanism. Federal Reserve Bank of New York Economic Policy Review 5: 9-28.

22. Elbourne A, J De Haan (2006) Financial Structure and Monetary Policy Transmission in Transition Countries. Journal of Comparative Economics 34 $1-23$.

23. Smets F (2013) Financial Stability and Monetary Policy: How Closely Interlinked? Sveriges Riksbank Economic Review 3: 121-160.

24. Norden L, Buston CS, Wagner W (2014) Financial Innovation and Bank Behavior: Evidence from Credit Markets. Journal of Economic Dynamics and Control 43: 130-145

25. Cecchetti SG, Krause S (2001) Financial Structure, Macroeconomic Stability and Monetary Policy. NBER Working Paper No. 8354.

26. Levine R, Loayza N, Beck T (2000) Financial Intermediation and Growth: Causality and Causes. Journal of Monetary Economics 46: 31-77.

27. Levine R (2004) Finance and Growth: Theory and Evidence. Handbook of Economic Growth.

28. Do QT, Levchenko A (2007) Comparative Advantage, Demand for External Finance, and Financial Development. Journal of Financial Economics 86: 796834

29. Krause S (2006) Optimal Monetary Policy and the Equivalency between the One-Period AD-AS Model and the Forward-Looking New Keynesian Model. Applied Economics Letters 13: 541-544.

30. Cecchetti SG (1998) Policy Rules and Targets: Framing the Central Banker's Problem. Economic Policy Review 4: 1-14.

31. Goldsmith R (1969) Financial Structure and development. New Haven: CT Yale U. Press.

32. Beck T, Levine R (2002) Industry Growth and Capital Allocation: Does having a Market- or Bank-Based System Matter? Journal of Financial Economics 64: 147-180.

33. Beck T, Levine R, Loayza N (2000) Finance and the Sources of Growth Journal of Financial Economics 58: 261-300.

34. McKinnon RI (1973) Money and Capital in Economics Development Washington, The Brooking Institution.

35. Shaw ES (1973) Financial Deepening in Economic Development. New York Oxford University Press.

36. King RG, Levine R (1993) Finance and Growth: Schumpeter Migth be Right The Quarterly Journal of Economics 108: 717-737.

37. Saxegaard M (2006) Excess Liquidity and effectiveness of Monetary Policy: Evidence from Sub-Saharan Africa. International Monetary Fund.

38. Gori F, Li BG, Presbitero AF (2015) Capital Flows and Financial Deepening in Developing Economies. In World Economic Outlook, International Monetary Fund.

39. Mussa M, Masson P, Swoboda A, Jadresic E, Mauro P, et al. (2000) Exchange Rate Regimes in an Increasing Integrated World Economy. Washington, D.C: IMF. 